\title{
Response of Wheat Plants to Irrigation with Magnetized Water under Egyptian Soil Conditions
}

\author{
Shaimaa H. Abd-EIrahman ${ }^{1}$ and Osama A. Shalaby ${ }^{2}$ \\ ${ }^{1}$ Soils and Water Department, Faculty of Agriculture 11241, Ain Shams University \\ and ${ }^{2}$ Plant Production Department, Desert Research Center, Cairo, Egypt
}

\begin{abstract}
$\mathbf{A}$ MAGNETIC device was designed and manufactured to assess the implications of using magnetized saline water for crop irrigation on plant growth parameters and properties of soils grown thereon. To reach this aim, four soil types differing in their textures and contents of soluble salts, were sampled, uniformly packed in PVC columns and then cultivated with wheat grains (Triticum aestivum L.). Two weeks later, plants received one of the following treatments for water irrigation i.e., tap water $\left(0.4 \mathrm{dS} \mathrm{m}^{-1}\right)$, magnetized tap water, saline water $\left(7.5 \mathrm{dS} \mathrm{m}^{-1}\right)$ and magnetized saline water at a rate of $100 \%$ of field capacity (FC) to collect water draining from each column. Significant improvements in both the growth and yield parameters of wheat as well as in the soil chemical properties (i.e. $\mathrm{pH}, \mathrm{EC}, \mathrm{Na}^{+}, \mathrm{Cl}^{-}, \mathrm{SAR}$, available $\mathrm{N}$, $\mathrm{P}$ and $\mathrm{K}$ contents) occurred due to irrigation with the magnetized saline water compared to irrigation with the non-magnetized saline ones. This magnetized waters seemed to increase the leachability of salts downwards the soil columns. The corresponding increases attained by magnetized saline water were higher than those attained by magnetized tap water. Also, NPK contents increased significantly within the different plant parts owing to magnetizing the irrigation water. Moreover, phosphorus fertilizer use efficiency increased significantly due to the irrigation with the magnetized waters i.e., the saline or the non-saline one compared with those received the non-magnetized waters. In conclusion, magnetizing irrigation water of low quality might reduce its negative implications on the grown plants and minimize accumulation of salts with the surface top soil.
\end{abstract}

Keywords: Magnetized saline water, Clayey soil, Sandy soil, Salt-affected soils, Salt movement, Wheat plant.

\section{Introduction}

Salinity is a major environmental challenge affecting seriously plant growth and production. The salinity problem is even worth in arid and semiarid regions where about one third of the world irrigated lands suffer from secondary salinization (Munns and Tester, 2008). The injurious effects of salinity on plants are associated with ionic, osmotic and oxidative stresses (Mansour, 2013). Ionic components of salinity are related to toxicity of particular ionic species (e.g., $\mathrm{Na}^{+}$and/ or $\mathrm{Cl}^{-}$stress) to plants as well as nutrient imbalance (Mansour et al., 2015). The high soil salt concentration reduces the soil water potential resulting in osmotic stress or water deficit (Sharma et al., 2012). Salt stress also induces formation of singlet oxygen, superoxide anion, hydrogen peroxide and hydroxyl radical and hence causes oxidative stress in many plants (Sharma et al., 2012).
The water treated with the magnetic field or passes through a magnetic device is called magnetized water (MW). The magnetic treatment of water has been reported to change some physical and chemical properties of water such as surface tension, refractive index, viscosity, melting temperature, conductivity, solubility of salts and $\mathrm{pH}$ (Grewal and Maheshwari, 2011). It restructures the water molecules into very small clusters (the magnetic fields weaken the intra clusters hydrogen bonds, breaking the larger clusters, forming smaller clusters with stronger inter cluster hydrogen bonds, Wang et al., 2013), each is made up of six symmetrically organized molecules. This tiny and uniform cluster has hexagonal structure thus it can easily enter the passage ways in plant and animal cell membranes (Wang et al., 2013). In addition, toxic agents cannot enter the MW structure. These features make MW a bio-friendly compound for plant and animal cells (Wang et al., 2013). MW can be used 
to increase crop yield, induce seed germination and benefit the health of livestock (Hilal et al., 2013). Studies have demonstrated that using MW for irrigation can improve water productivity; thus, conserving water supplies for the expected future global water scarcity. In addition, MW is reportedly effective at preventing and removing scale deposits in pipes and water containing structures (Ali et al., 2014). The main functions of magnetic treated water in soil are increasing the leaching of excess soluble salts, lowering $\mathrm{pH}$ values of soil layers, dissolving slightly soluble salts such as carbonates, phosphates and sulfates (Hilal et al., 2013), decreasing the hydration of salt ions, accelerating coagulation and salt crystallization, increasing the efficiency of added fertilizers, increasing nutrient mobility in soil and enhancing extraction and uptake of N, P, K, Fe and $\mathrm{Zn}$ by plants (Shalaby, 2012 and Ali et al., 2014), improving the microbiological content of soil (Ratushnyak et al., 2008) and making plants more resistant to unfavorable environmental conditions (Alikamanoglu and Sen, 2011).

Wheat (Triticum aestivum L.) is a strategic crop that can grow under different soil conditions. Thus, the main objective of this study is to evaluate the effect of irrigation with saline water ( $\left.7.5 \mathrm{dS} \mathrm{m}^{-1} \sim 65 \mathrm{mM} \mathrm{NaCl}\right)$ and magnetized saline water compared to tap water and magnetized tap water on salt movement beside its relevant chemical properties in soils packed in columns. Soils were collected from different regions i.e. Ras Sudr (saline sandy soil), El-Hosinia Plain (saline clay soil), Siwa Oasis (sandy soil) and the experimental farm of Faculty of Agriculture, Ain Shams University (clay soil). Wheat plant growth and yield properties were also a matter of concern in this investigation.

\section{Materials and Methods}

\section{Soils of study}

Four soil samples differing in their physical and chemical properties, were selected to attain the aim of the current study. The first one represents a saline sandy soil collected from Ras Sudr (South Sinai governorate). The second sample represents a saline clay one collected from North of El-Hosinia Plain (Sharkia governorate) and the third one represents a sandy soil collected from Siwa Oasis (Matrouh governorate). The fourth soil sample represents a clay one collected from the experimental farm of Faculty of Agriculture, Ain Shams Univ., Qalubia governorate. The abovementioned soils were sampled at a depth of 0-20 cm, air dried, grounded to pass through a $2 \mathrm{~mm}$ sieve and then analyzed for their physical and chemical characteristics according to the standard methods outlined by Klute (1986) and Page et al. (1982). The obtained results are presented in Table 1.

TABLE 1. Some physical and chemical characteristics of the studied soils

\begin{tabular}{|c|c|c|c|c|}
\hline Character & Ras Sudr & Siwa Oasis & El-Hosinia Plain & Exp. Farm of Fac. Agric. \\
\hline \multicolumn{5}{|l|}{ Particle size distribution, $\%$} \\
\hline Sand & 73.9 & 96.5 & 13.5 & 20.7 \\
\hline Silt & 14.7 & 1.93 & 27.4 & 23.9 \\
\hline Clay & 11.4 & 1.57 & 59.1 & 55.4 \\
\hline Textural class & Sandy loam & Sandy & Clay & Clay \\
\hline Field capacity, \% & 12.1 & 8.50 & 55.3 & 50.9 \\
\hline $\mathrm{CaCO}_{3}, \mathrm{~g} \mathrm{~kg}^{-1}$ & 495 & 53.0 & 61.0 & 11.6 \\
\hline $\mathrm{OM}, \mathrm{g} \mathrm{kg}^{-1}$ & 1.30 & 0.50 & 12.3 & 11.0 \\
\hline $\mathrm{CEC}, \mathrm{cmol}_{\mathrm{c}} \mathrm{kg}^{-1}$ & 10.3 & 8.85 & 48.1 & 45.5 \\
\hline pH (1:2.5 soil:water suspension) & 8.09 & 8.29 & 7.78 & 7.47 \\
\hline $\mathrm{EC}_{\mathrm{e}}, \mathrm{dS} \mathrm{m}^{-1}$ & 9.97 & 0.92 & 6.20 & 0.49 \\
\hline \multicolumn{5}{|l|}{ Soluble ions, $\mathrm{mmol}_{\mathrm{c}} \mathrm{L}^{-1}$} \\
\hline $\mathrm{Ca}^{2+}$ & 18.8 & 6.80 & 16.2 & 3.20 \\
\hline $\mathrm{Mg}^{2+}$ & 9.80 & 6.40 & 14.6 & 3.00 \\
\hline $\mathrm{Na}^{+}$ & 84.8 & 2.10 & 45.5 & 0.90 \\
\hline $\mathrm{K}^{+}$ & 0.60 & 0.50 & 1.10 & 0.90 \\
\hline $\mathrm{HCO}_{3}^{-}$ & 8.00 & 3.42 & 7.72 & 2.65 \\
\hline $\mathrm{Cl}^{-}$ & 80.5 & 4.20 & 47.4 & 1.22 \\
\hline $\mathrm{SO}_{4}^{2-}$ & 22.4 & 3.16 & 13.8 & 2.06 \\
\hline SAR & 33.3 & 1.05 & 16.4 & 0.69 \\
\hline \multicolumn{5}{|l|}{ Available macronutrient, $\mu \mathrm{g} \mathrm{g}^{-1}$} \\
\hline $\mathrm{N}$ & 14.4 & 12.5 & 35.3 & 31.8 \\
\hline $\mathrm{P}$ & 1.72 & 1.84 & 3.01 & 2.88 \\
\hline $\mathrm{K}$ & 87.3 & 79.5 & 170 & 154 \\
\hline
\end{tabular}

Egypt. J. Soil Sci. 57, No.4 (2017) 


\section{Technique of magnetizing the water}

Authors of this study manufactured a device for magnetizing the irrigation water which flows through it. The device was manufactured using a plastic tube of $16 \mathrm{~mm}$ diameter and $50 \mathrm{~cm}$ length. Ten units of identified permanent magnets were arranged in uni-polar configuration (facing the magnetic poles), so that the distance between each two magnets was $8 \mathrm{~cm}$. The intensity of the magnet was 800 Gauss. In order to implement the irrigation water treatments, a big water container with tap $(50 \mathrm{~L})$ was used, and the water flow rate was fixed in all treatments. For the magnetically water treatment, the magnetic field unit has been attached to the tap of the container and the water was passed through it, then the magnetized water was collected into a smaller container to use it in the irrigation. The same procedure was applied both in tap or saline water.

\section{Columns experiment}

Sixteen PVC columns $(60 \mathrm{~cm}$ length and 20 $\mathrm{cm}$ internal diameter) were uniformly packed with each of the investigated soils to a height of $55 \mathrm{~cm}$. Thereafter, the columns were arranged in a randomized block design under the greenhouse conditions of the Faculty of Agriculture, Ain Shams University (Qalubia governorate, Egypt).

Salt tolerant wheat grains (Triticum aestivum, c.v Sakha 93) were cultivated in the studied soil columns on $18^{\text {th }}$ November 2015 , at a rate of 10 grains per column and then irrigated with tap water for two weeks. Afterwards, four irrigation treatments were applied, i.e. irrigation with tap water $\left(0.4 \mathrm{dS} \mathrm{m}^{-1}\right)$, magnetized tap water, saline water $\left(7.5 \mathrm{dS} \mathrm{m}^{-1} \sim 65 \mathrm{mM} \mathrm{NaCl}\right)$ and magnetized saline water. The soil columns received irrigation water in excess $(100 \%$ of FC) to allow water to drain from each column. The recommended doses of mineral NPK fertilizers were applied as recommended by the Ministry of Agriculture, Egypt, i.e. $180 \mathrm{~kg} \mathrm{~N} \mathrm{ha}^{-1}$ in the form of ammonium sulfate, $7.85 \mathrm{~kg} \mathrm{P} \mathrm{ha}^{-1}$ in the form of ordinary superphosphate and $26.9 \mathrm{~kg} \mathrm{~K} \mathrm{ha}^{-1}$ in the form of potassium sulfate $\left(120 \mathrm{~kg} \mathrm{~K}_{2} \mathrm{SO}_{4} \mathrm{ha}^{-1}\right)$. Plants were harvested on the $3^{\text {rd }}$ of April 2016 and the following growth parameters i.e. plant height, dry weight of whole plant and dry weight of 1000 grains were determined.

\section{Soil, water and plant analyses}

Chlorophyll content was measured on the fifth mature leaf from top using Minolta chlorophyll meter Spad-501. Proline content (indication of stress) was also a matter of concern in the current study and was determined in the fresh leaves of the harvested plants according to the method of Troll and Lindsley (1955) modified by Peters et al. (1997). Afterwards, plants were separated into roots, shoots and grains, oven dried at $70^{\circ} \mathrm{C}$ for $48 \mathrm{~h}$ and then digested using an acid mixture of $\mathrm{H}_{2} \mathrm{SO}_{4} / \mathrm{H}_{2} \mathrm{O}_{2}$ according to the method described by Chapman and Pratt (1961). On the other hand, soil samples were collected at depths of 0 to 20 , 20 to 40 and 40 to $55 \mathrm{~cm}$ from each column after plant harvest. The collected samples were air dried, crushed and sieved through a $2 \mathrm{~mm}$ sieve. The collected drained water was filtered and stored at $4^{\circ} \mathrm{C}$ for analysis. The prepared soil, water and plant samples were subjected to the studied chemical analyses according to the methods described by Page et al. (1982) and Chapman and Pratt (1961).

The obtained data were then statistically analyzed using SAS software package. The means that were significant were separated using Duncan's multiple range test at $\mathrm{P} \leq 0.05$ (SAS, 1996).

\section{Results and Discussions}

\section{Soil chemical properties}

Soil pH

Soil $\mathrm{pH}$ decreased significantly with increasing soil depth as shown in Fig.1. Irrigation with the magnetized saline water recorded the highest reduction in soil $\mathrm{pH}$, followed by irrigation with the magnetized tap water. This result coincides with those obtained by Hilal et al. (2013) and Hashemabadi et al. (2015). This probably occurred because of the changes in the arrangement of particles and polarization of the solution that took place when the liquids passed through the magnetic field (Amer et al., 2014). Lowering $\mathrm{pH}$ might exist in the saline soils when salts compress the electrical double layer of soil colloids, thus released $\mathrm{H}^{+}$ions free in the soil solution. Also, leaching salts from soil profile and adsorb $\mathrm{H}^{+}$ions instead of the other cations on clay and organic fractions, may lead to decrease the $\mathrm{pH}$ of the studied soils. The sandy soil of Siwa Oasis recorded the least values of soil $\mathrm{pH}$ then the saline clay soil of El-Hosinia Plain, followed by the clay soil of the experimental farm of Faculty of Agriculture and saline sandy soil of Ras Sudr. Buffering capacity of the studied soils seemed to be the most effective factor regardless of soil texture.

\section{Electrical conductivity (EC)}

The values of soil EC increased significantly with increasing soil depth (Fig. 2). Such a result was more obvious in all the studied soils irrigated 
with the magnetized water. This might indicate the higher efficiency of the magnetized water in leaching soluble salts out of the soil profile than the non-magnetized water. The magnetic field might change hydrogen bonds between water molecules and rebuilt them in hexagonal structure consequently increased the leachability of the soluble salts. Moreover, the magnetic field probably destroyed the big crystals of salts into smaller ones to pass more easily through the soil pores. Several researchers confirmed that the magnetized water increased solubility and leachability of salts from the soil profile (Amer et al., 2014 and Hilal et al., 2013). The clay soils recorded less efficiency in the leachability of soluble salts throughout the soil columns than the sandy soils did.

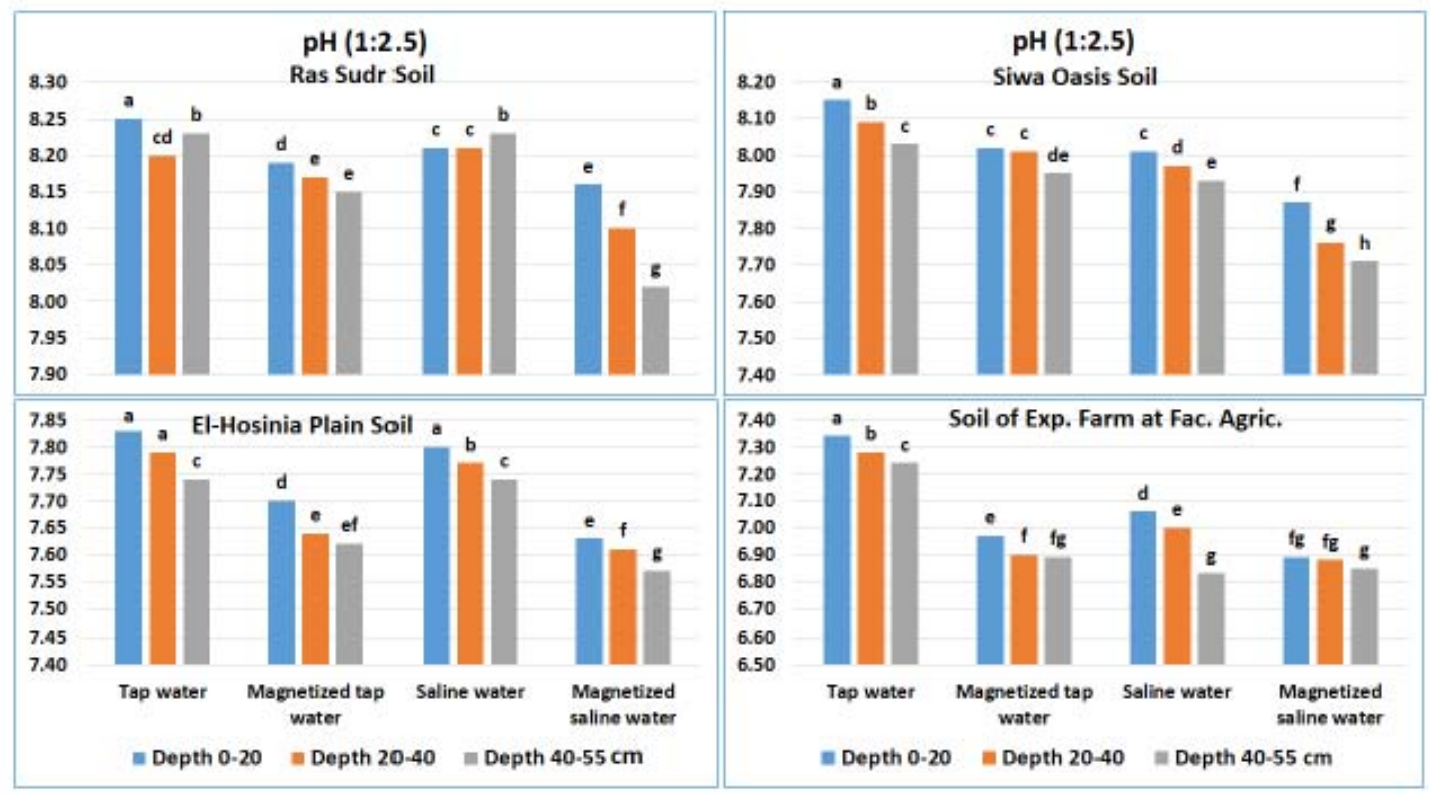

Fig. 1. pH values of the different depths of the studied soil columns as affected by irrigation with different water types

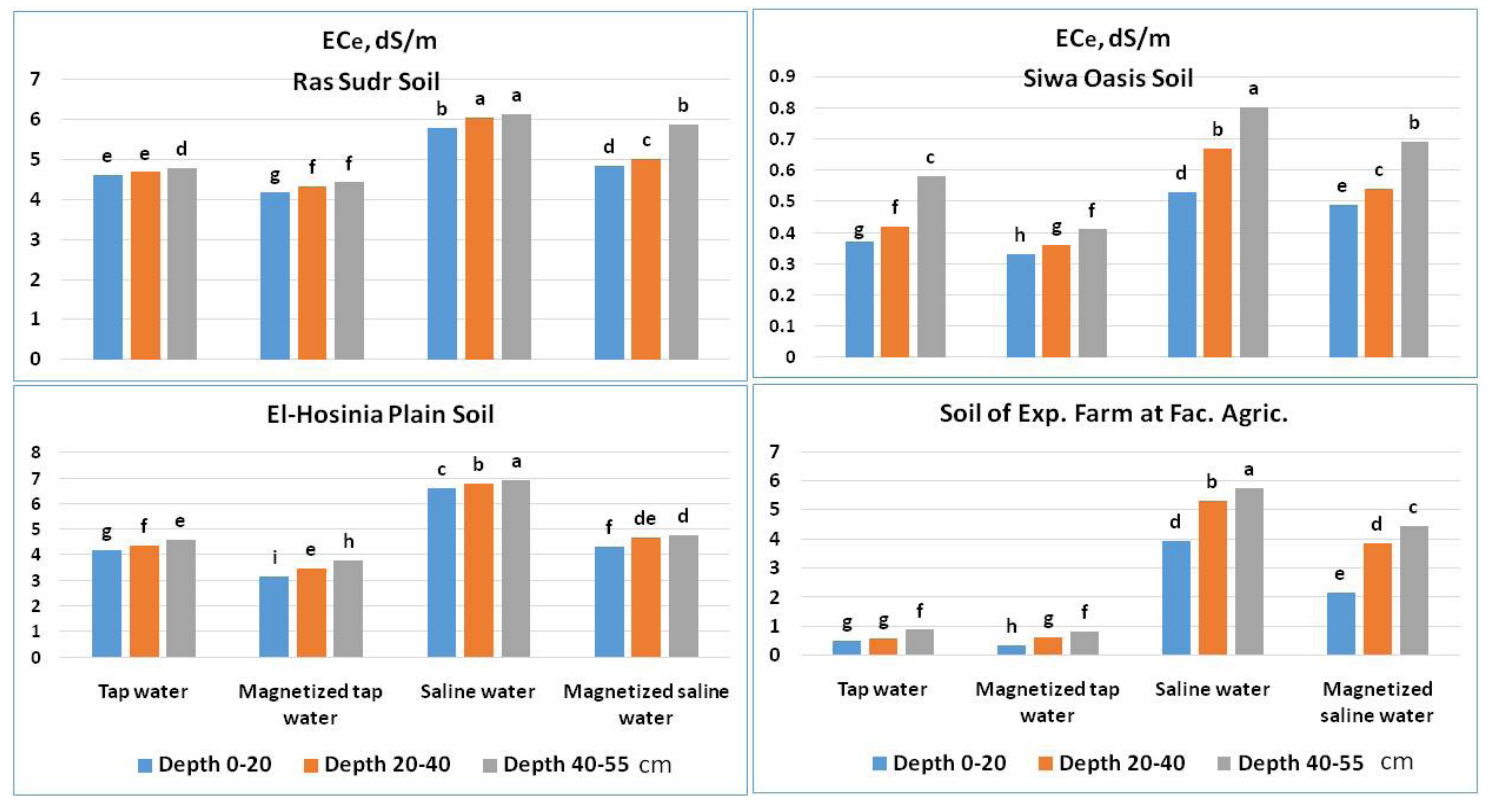

Fig. 2. $\mathrm{EC}_{\mathrm{e}}$ values of the different depths of the studied soil columns as affected by irrigation with different water types 
Soluble sodium and chloride ions

Soluble sodium is an important parameter affecting soil quality. Fig. 3 reveals that soluble $\mathrm{Na}^{+}$ concentrations increased significantly in soils with increasing soil depth while decreased significantly when using the magnetized water for irrigation. Soils of heavier texture preserved higher concentrations of $\mathrm{Na}^{+}$ions exceeding those found in the sandy ones. Irrigation with saline water increased soil content of $\mathrm{Na}^{+}$compared to the same soil irrigated with tap water. Chloride ions, as an ionic component of salinity, showed similar trend to that of $\mathrm{Na}^{+}$ions in the studied soils (Fig. 4). Irrigation with the magnetized water whether the tap or saline ones decreased significantly the concentrations of such ions within the surface soil segments while increased significantly their concentrations within the lower soil segments. There might be an effective downward leaching of salts from the surface soil segments when using the magnetized water for irrigation, consequently the EC of the water drained from the soil columns might be higher. The soils irrigated with magnetized tap water could be arranged according to their contents of $\mathrm{Cl}^{-}$ions in the following descending order: soil of El-Hosinia Plain > soil of Ras Sudr > soil of the experimental farm of Faculty of Agriculture $>$ soil of Siwa Oasis. Irrigation with magnetized saline water increased $\mathrm{Cl}^{-}$ions in Ras Sudr soil which contained amounts of such ions exceeded the corresponding ones of El-Hosinia Plain soil, followed by soil of the experimental farm of Faculty of Agriculture and with small amount in Siwa Oasis soil. The higher amount of $\mathrm{CaCO}_{3}$ in Ras Sudr soil may play a similar role to that played by the clay in El-Hosinia Plain soil.

\section{Sodium adsorption ratio (SAR)}

Sodium adsorption ratio was calculated for the studied soils after irrigation and the results are presented in Fig. 5. These values significantly increased with increasing the soil depth inside columns. Results indicated that irrigation with magnetized water significantly increased solubility of $\mathrm{Ca}^{2+}$ and $\mathrm{Mg}^{2+}$ ions in the studied soils compared to irrigation with tap water. Thus SAR values decreased significantly in soils irrigated with magnetized water (tap or saline water). In this concern, the reductions occurred in SAR values were more obvious when using the magnetized tap water for irrigation rather than the magnetized saline water. SAR values could be arranged in the following descending order: ElHosinia Plain soil $>$ Ras Sudr soil $>$ soil of the experimental farm of Faculty of Agriculture $>$ Siwa Oasis soil.

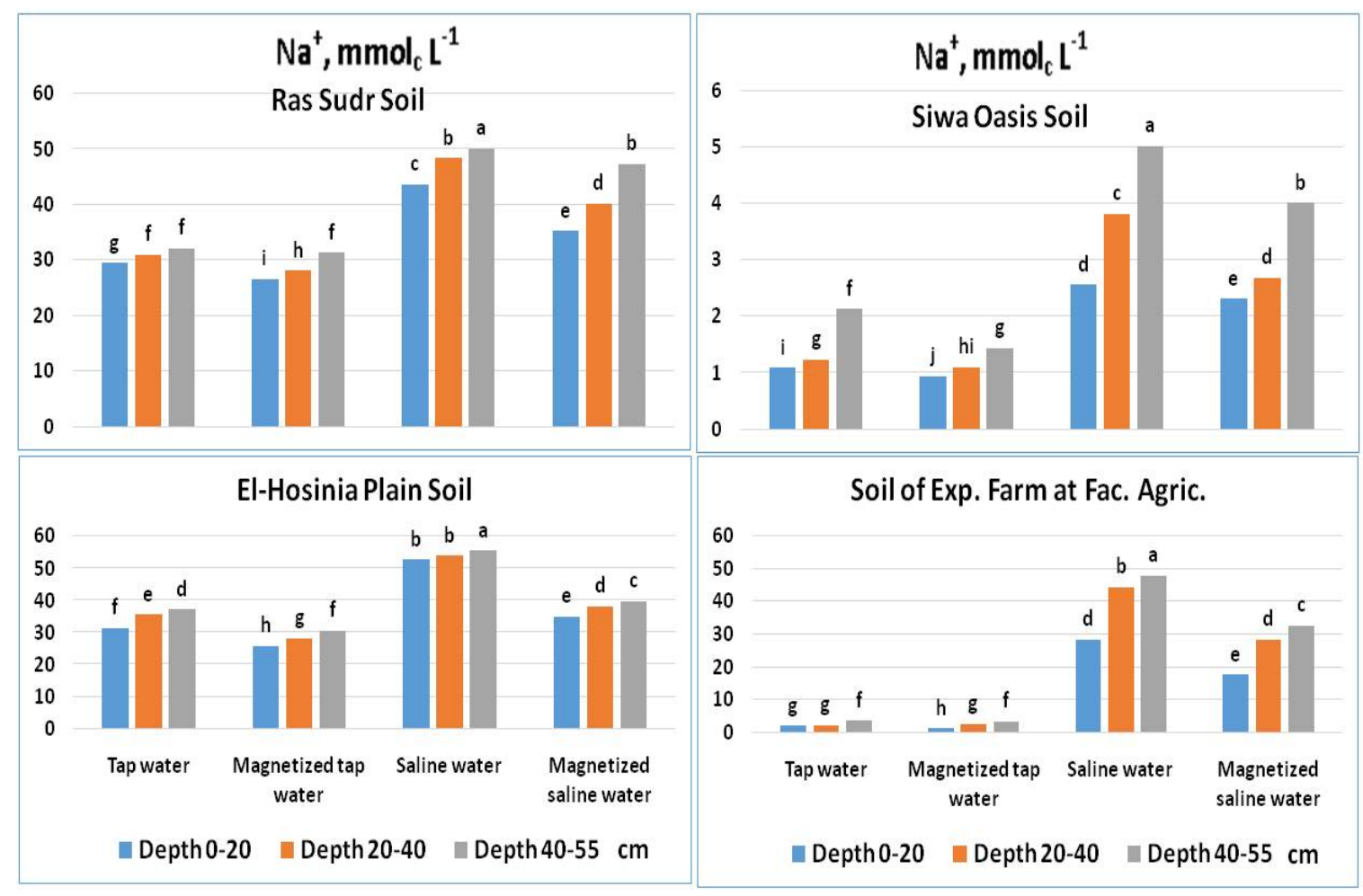

Fig. 3. Soluble sodium concentration values of the different depths of the studied soil columns as affected by irrigation with different water types 


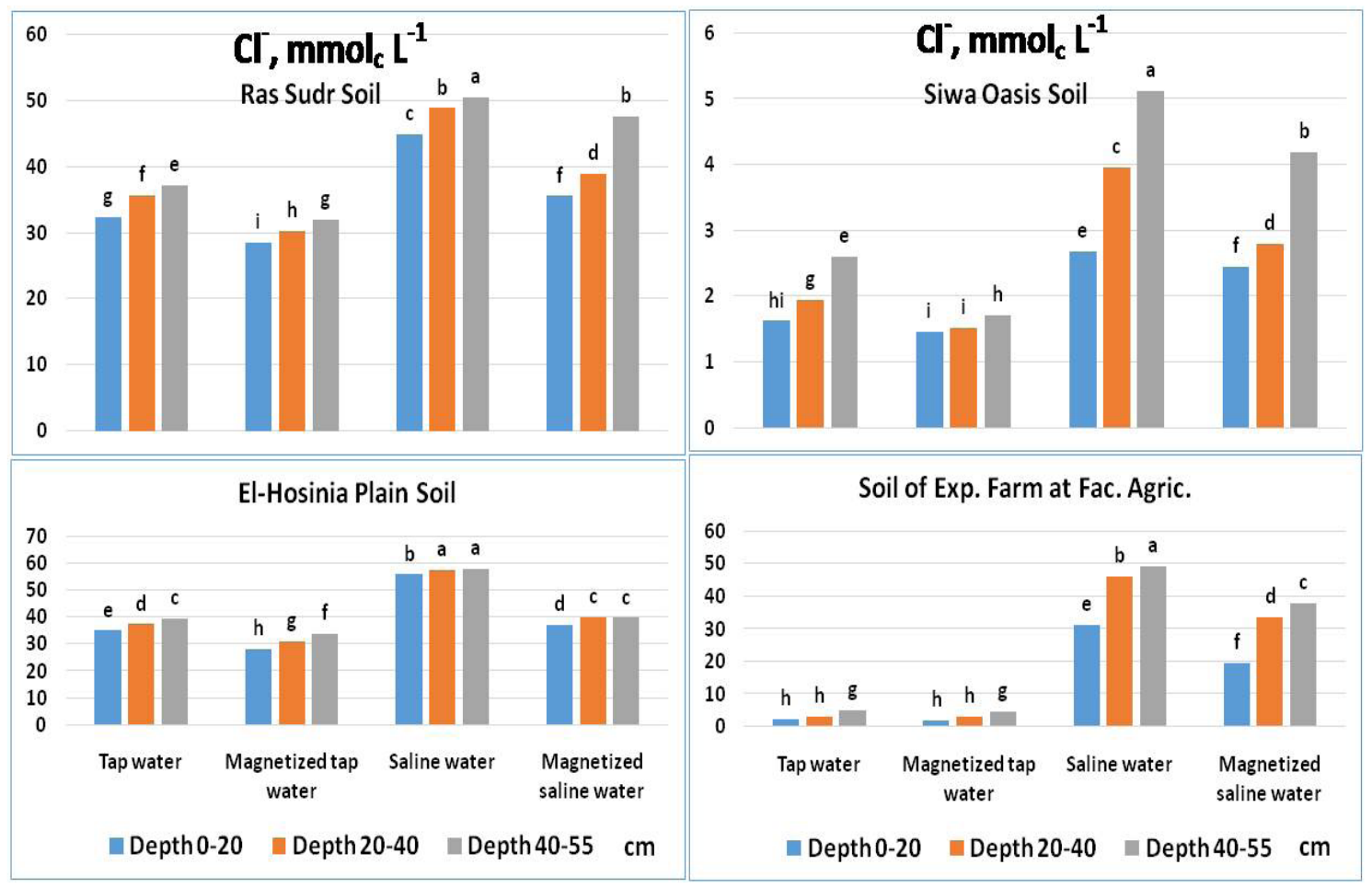

Fig. 4. Soluble chloride concentrationvalues of the different depths of the studied soil columns as affected by irrigation with different water types

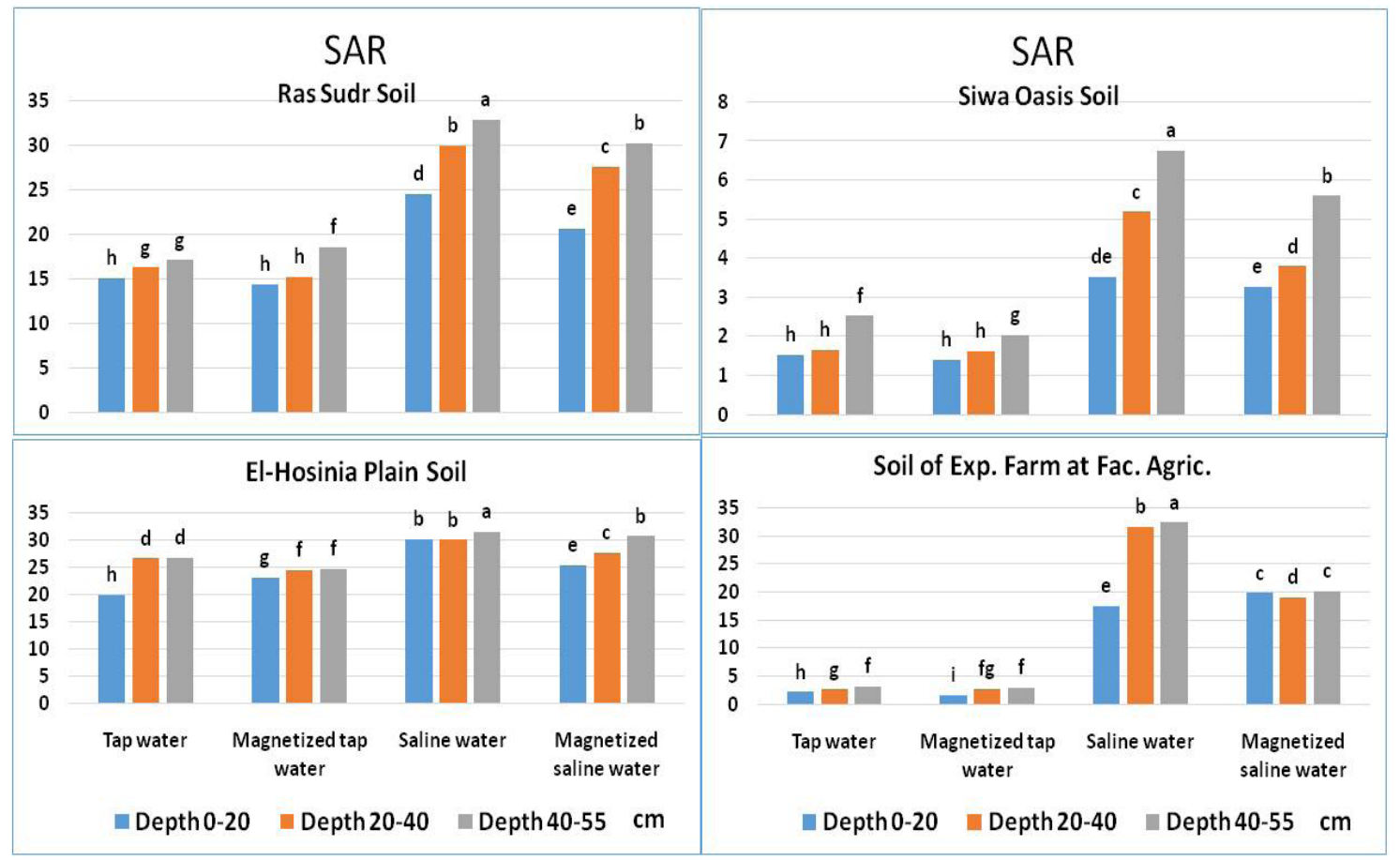

Fig. 5. Sodium adsorption ratio (SAR) values of the different depths of the studied soil columns as affected by irrigation with different water types

Egypt. J. Soil Sci. 57, No.4 (2017) 
Chemically available concentration of $N, P$ and $K$

Data illustrated in Fig. 6 show that available $\mathrm{N}$ increased significantly in soils with increasing soil depth. Such increases were higher when soils irrigated with magnetized tap water rather than irrigation with magnetized saline water. Available $\mathrm{N}$ could be placed according to its content in the following descending sequence: soil of ElHosinia Plain $>$ soil of the experimental farm of Faculty of Agriculture $>$ soil of Ras Sudr $>$ soil of Siwa Oasis. This finding may be due to the higher indigenous fertility and CEC values of the clay soils compared to the corresponding ones of the sandy soils. Data illustrated in Fig. 7 show that magnetized water retained more available $P$ in soil than the non-magnetized water did. Data illustrated in Fig. 8 show that values of chemically available $\mathrm{K}$ concentration in the studied soil columns followed a trend almost similar to those attained previously with $\mathrm{N}$ and $\mathrm{P}$. These results agree with those obtained by Shalaby (2012) and Ali et al. (2014). $p H$ and $E C_{d}$ of the waters drained from the studied soil columns

Data illustrated in Fig. 9 show that $\mathrm{pH}$ values significantly decreased in drainage water due to irrigation with magnetized water and such reductions were more obvious upon irrigation with the saline water rather than the tap (normal) water. Magnetized waters seemed to increase the leachability of salts out of the soil columns. However, the increases were higher with magnetized saline water more than magnetized tap water. $\mathrm{EC}_{\mathrm{d}}$ values of the water drained from saline sandy soil columns were more than those drained from saline clay soil columns, followed by those drained from sandy soil of Siwa Oasis columns and from clay soil of the experimental farm of Faculty of Agriculture columns, respectively. Soil texture control passes of soluble salts and cations exchange, which reflect on their amount in drainage water.

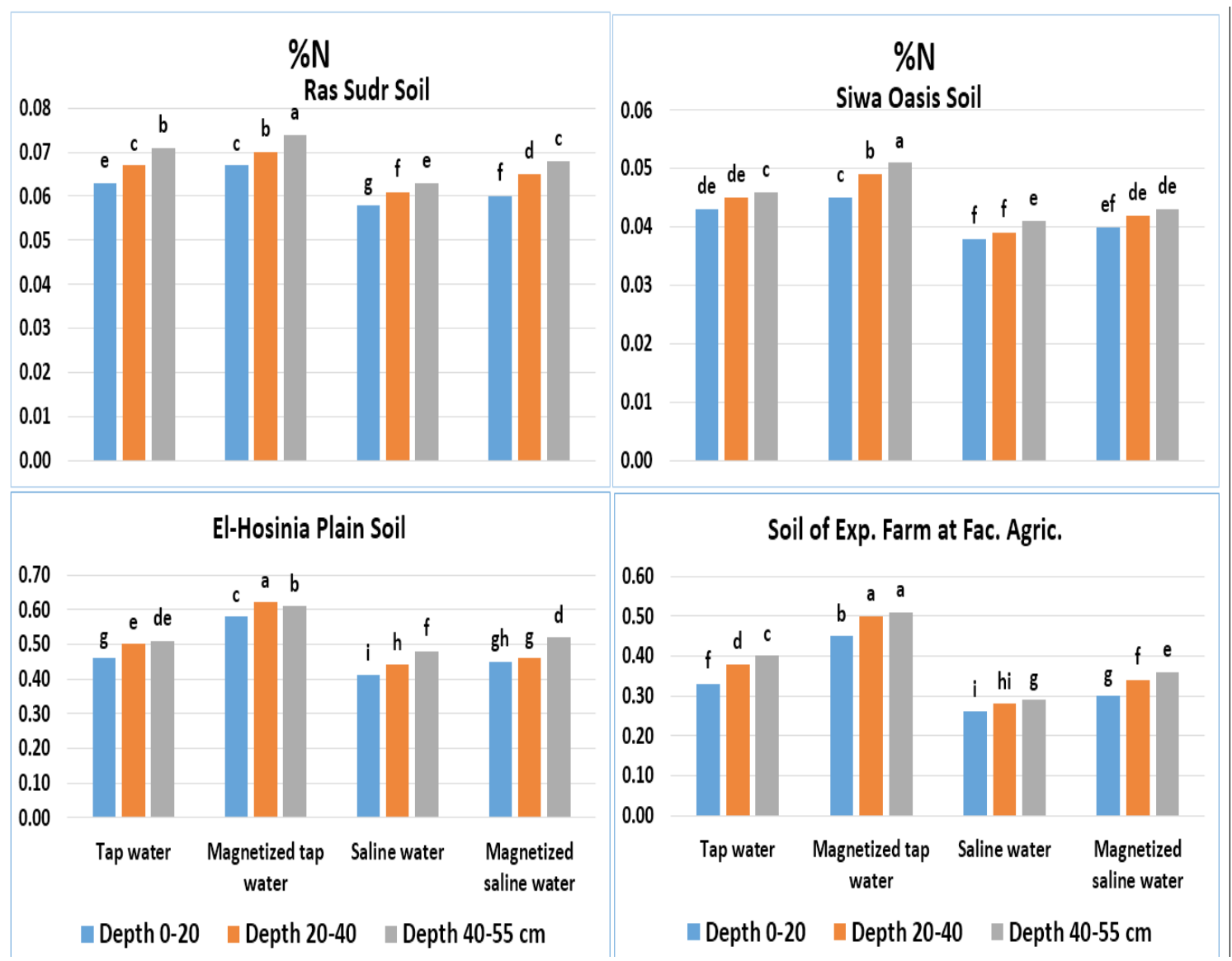

Fig. 6. Chemically available $\mathrm{N}(\%)$ of the different depths of the studied soil columns as affected by irrigation with different water types 


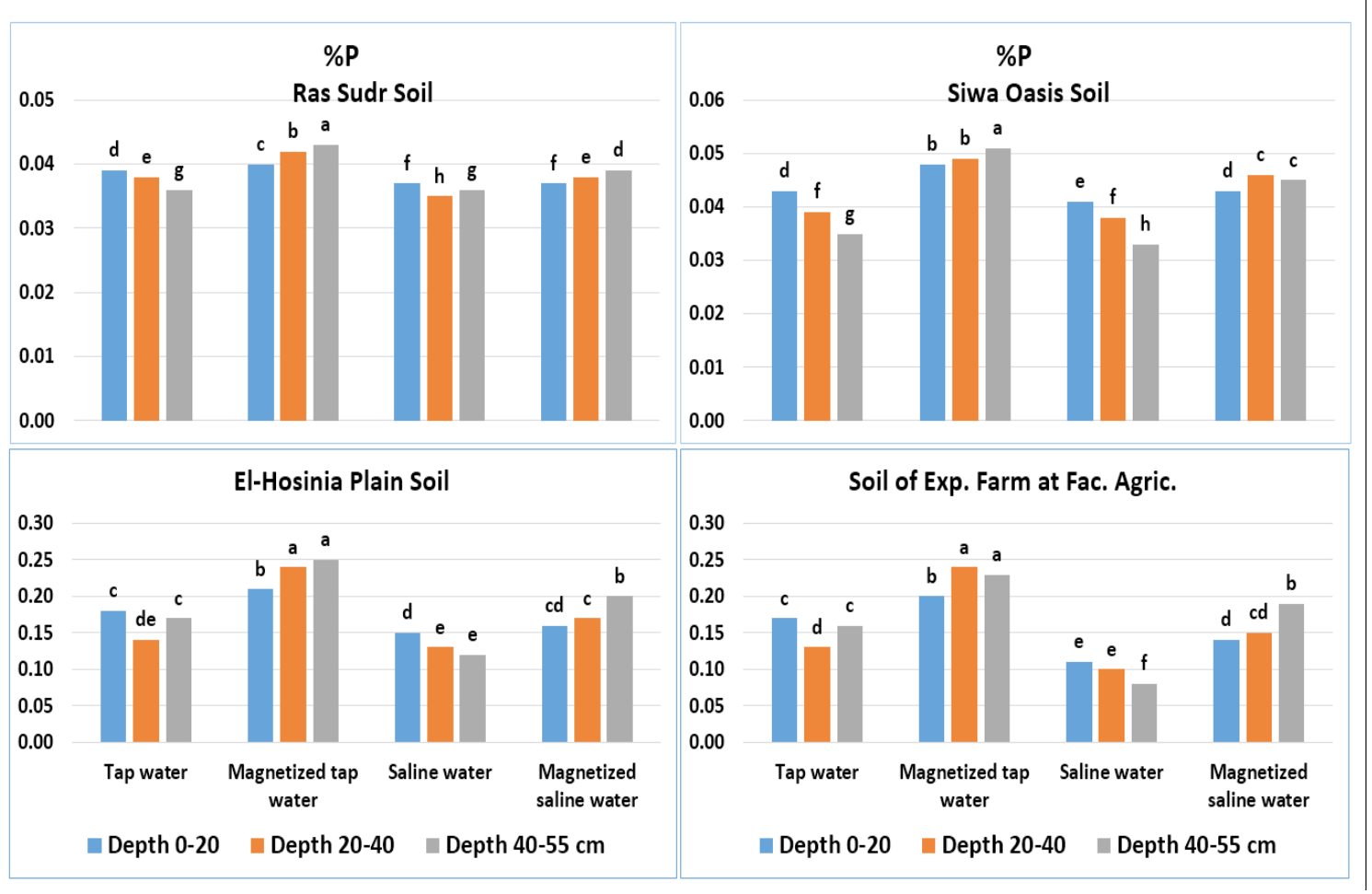

Fig. 7. Chemically available $P(\%)$ of the different depths of the studied soil columns as affected by irrigation with different water types

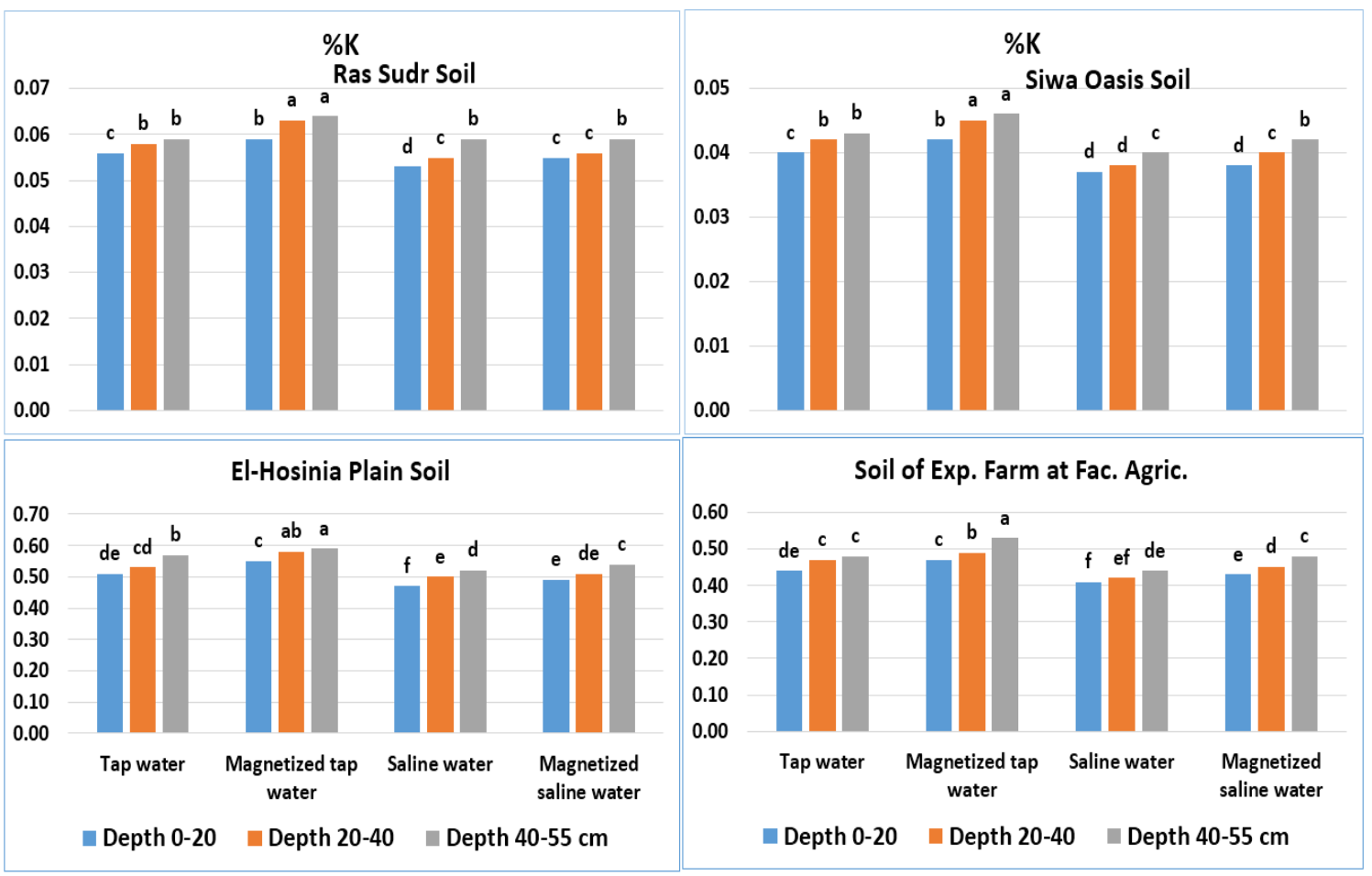

Fig. 8. Chemically available $\mathrm{K}(\%)$ of the different depths of the studied soil columns as affected by irrigation with different water types 


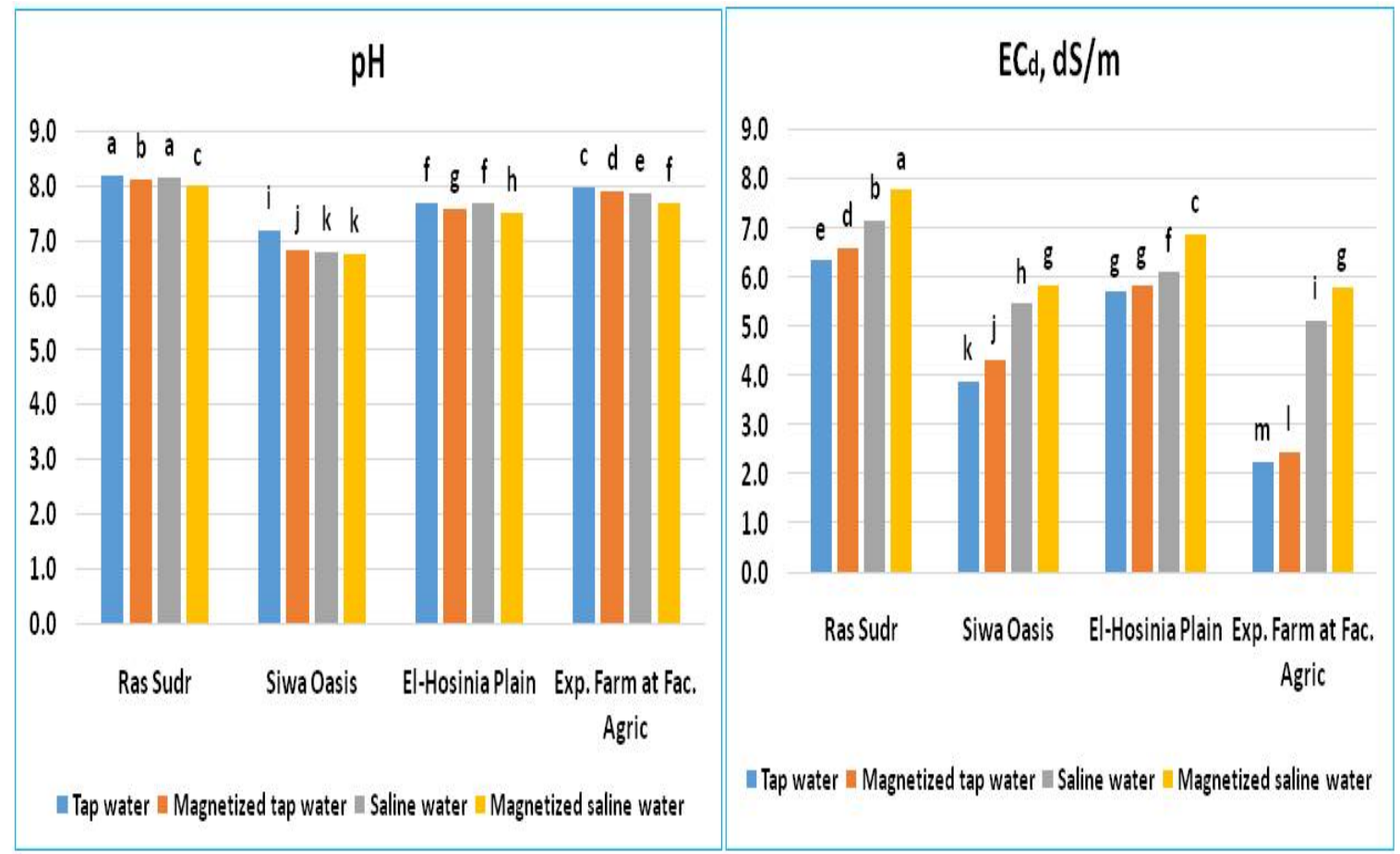

Fig. 9. $\mathrm{pH}$ and $\mathrm{EC}_{\mathrm{d}}$ values of the water drained out from the studied soil columns as affected by irrigation with different types of water

\section{Wheat plant}

Data in Table 2 show the effect of different irrigation water treatments on wheat growth, the outcome yield and the elemental composition within plants. Generally, there were significant reductions in the studied growth parameters of the plants grown on the saline soils compared to the non-saline ones. Plant height ranged from $24 \mathrm{~cm}$ (in the saline sandy soil irrigated with saline water) to $47 \mathrm{~cm}$ (in the non-saline soil irrigated with the magnetized tap water). Likewise, plant dry weights as well as the weight of 1000 grains showed a similar trend. Generally, the growth and yield parameters of wheat plants showed better trend in the nonsaline soils compared to the saline ones. Also, these parameters were higher in the clayey soils than in the sandy ones. There are some changes occurred in the physical and chemical properties of water due to the magnetic treatment, mainly hydrogen bonding, polarity, surface tension, conductivity, $\mathrm{pH}$ and solubility of salts, and these changes in water properties may be capable of affecting the growth and reflect on the yield of growing plants (Grewal and Maheshwari, 2011).

Chlorophyll content in wheat plants leaves (Table 2) decreased under saline stress while increased significantly under irrigation with magnetized water. This may be due to the effect of magnetized water on reducing saline stress by increasing salt movement through the soil profile. This result agrees with those obtained by Mafakheri et al. (2010) who reported that the total chlorophyll content in wheat plants significantly decreased under stresses. Proline content increased significantly in wheat plants irrigated with the non-magnetized saline water compared to magnetized saline one, especially for those grown under saline conditions i.e. Ras Sudr and El-Hosinia Plain soils. Such increases might be a mode of defense to raise the osmotic pressure inside the plant cells to face the stress (Abu-Elsoud and Abd-Elrahman, 2016).

The elemental content of $\mathrm{N}, \mathrm{P}$ and $\mathrm{K}$ within the different parts of wheat plants grown on the studied soils as affected by different irrigation water treatments are also shown in Table 2. Results revealed that concentration of $\mathrm{N}$ and $\mathrm{P}$ were significantly higher under irrigation with saline water compared to irrigation with magnetized ones (tap or saline water). Moreover, such concentrations were higher in plants grown on the clayey soils than corresponding ones obtained from plants grown on the sandy soils. Regarding the concentration of $\mathrm{K}$ in roots, shoots and grains, irrigation with magnetized tap water recorded the highest increases in $\mathrm{K}$ content in these organs, followed by non-magnetized tap water, then the magnetized saline water and

Egypt. J. Soil Sci. 57, No. 4 (2017) 
finally the non-magnetized saline water. It was obvious from the results that the movement of macronutrients from roots to grains was, generally, higher in plants irrigated with magnetized water compared to non-magnetized one. According to Ratushnyak et al. (2008) and Abou El-Yazied et al. (2012) irrigation with magnetic treated water increased the amount of microbial content of the soils such as N-fixation bacteria. Such increases may improve the availability of nutrients in the soil and consequently their uptake by plants. This could improve the efficiency of the amending mineral fertilizers. Also, the increases in the availability of soil nutrients might be attributed to soil acidification resulted from the increases in the released root exudates (organic acids) in the rhizosphere by plants irrigated with magnetized water (Maheshwari and Grewal, 2009).

\section{Conclusion}

It could be concluded that, the magnetic treatment of water used in irrigating saline soils could be a promising technique for the soil and agricultural improvements, besides this technique is considered a friendly environmental one. It's recommended to use the magnetized water for irrigation to save the irrigation water especially under water shortage conditions. Also, it might increase the fertilizers use efficiency. In addition, it improved significantly the vegetative growth and yield parameters beside the macronutrients content of wheat plants.

TABLE 2. Effect of different irrigation water treatments on growth, yield and elemental content of wheat plants grown on

\begin{tabular}{|c|c|c|c|c|c|c|c|c|c|c|c|c|c|c|}
\hline \multirow{2}{*}{ Treatment } & \multirow{2}{*}{$\begin{array}{c}\text { Plant } \\
\text { height, } \\
\text { cm }\end{array}$} & \multirow{2}{*}{$\begin{array}{c}\text { Dry weight } \\
\text { of whole } \\
\text { plant, } \\
\text { g/column }\end{array}$} & \multirow{2}{*}{$\begin{array}{c}\text { Weight } \\
\text { of } 1000 \\
\text { grains, } \\
\quad \mathrm{g}\end{array}$} & \multirow{2}{*}{$\begin{array}{l}\text { Chlorophyll } \\
\text { in leaves, } \\
\text { SPAAD }\end{array}$} & \multirow{2}{*}{$\begin{array}{c}\text { Proline in } \\
\text { leaves, } \\
\text { mg g }^{-1} \\
\text { FW }\end{array}$} & \multicolumn{3}{|c|}{$\mathrm{N}(\%)$} & \multicolumn{3}{|c|}{$\mathbf{P}(\%)$} & \multicolumn{3}{|c|}{ K (\%) } \\
\hline & & & & & & Root & Shoot & Grains & Root & Shoot & Grains & Root & Shoot & Grains \\
\hline & \multicolumn{14}{|c|}{ Ras Sudr Soil } \\
\hline TW* & $31.0 \mathrm{~g}$ & $2.17 \mathrm{j}$ & $25.0 \mathrm{~h}$ & $35.2 \mathrm{j}$ & $46.3 \mathrm{~d}$ & 1.171 & 1.221 & $1.26 \mathrm{~m}$ & 0.281 & $0.32 \mathrm{j}$ & $0.37 \mathrm{i}$ & $0.82 \mathrm{k}$ & $0.88 \mathrm{j}$ & $0.96 \mathrm{~h}$ \\
\hline MTW & $33.0 \mathrm{f}$ & $2.31 \mathrm{i}$ & $26.7 \mathrm{~g}$ & $36.9 \mathrm{i}$ & $45.5 \mathrm{~d}$ & $1.19 \mathrm{k}$ & $1.26 \mathrm{k}$ & 1.291 & $0.31 \mathrm{k}$ & $0.36 \mathrm{i}$ & $0.40 \mathrm{~h}$ & $0.87 \mathrm{j}$ & $0.91 \mathrm{i}$ & $1.03 \mathrm{~g}$ \\
\hline SW & $24.0 \mathrm{j}$ & 1.921 & $15.0 \mathrm{k}$ & 30.31 & $51.2 \mathrm{a}$ & $1.27 \mathrm{~h}$ & $1.35 \mathrm{~g}$ & $1.42 \mathrm{~h}$ & $0.37 \mathrm{~h}$ & $0.42 \mathrm{~g}$ & $0.47 \mathrm{f}$ & $0.68 \mathrm{~m}$ & 0.731 & $0.81 \mathrm{j}$ \\
\hline \multirow[t]{2}{*}{ MSW } & $25.8 \mathrm{j}$ & $2.05 \mathrm{k}$ & $19.0 \mathrm{j}$ & $32.4 \mathrm{k}$ & $49.0 \mathrm{~b}$ & $1.21 \mathrm{j}$ & $1.31 \mathrm{i}$ & $1.36 \mathrm{j}$ & $0.33 \mathrm{j}$ & $0.39 \mathrm{~h}$ & $0.45 \mathrm{~g}$ & 0.751 & $0.79 \mathrm{k}$ & $0.90 \mathrm{i}$ \\
\hline & \multicolumn{14}{|c|}{ Siwa Oasis Soil } \\
\hline TW & $42.0 \mathrm{c}$ & $4.05 \mathrm{c}$ & $34.3 \mathrm{~d}$ & $55.0 \mathrm{~d}$ & $32.4 \mathrm{j}$ & $1.25 \mathrm{i}$ & $1.28 \mathrm{j}$ & 1.291 & $0.33 \mathrm{j}$ & $0.36 \mathrm{i}$ & $0.38 \mathrm{i}$ & $0.94 \mathrm{~h}$ & $0.96 \mathrm{~h}$ & $0.98 \mathrm{~h}$ \\
\hline MTW & $44.0 \mathrm{~b}$ & $4.42 \mathrm{~b}$ & $43.7 \mathrm{c}$ & $56.7 \mathrm{c}$ & $31.0 \mathrm{k}$ & $1.27 \mathrm{~h}$ & $1.31 \mathrm{i}$ & $1.34 \mathrm{k}$ & $0.35 \mathrm{i}$ & $0.36 \mathrm{i}$ & $0.39 \mathrm{hi}$ & $1.02 \mathrm{~g}$ & $1.05 \mathrm{~g}$ & $1.07 \mathrm{f}$ \\
\hline SW & $34.0 \mathrm{f}$ & $2.45 \mathrm{~h}$ & $27.7 \mathrm{~g}$ & $39.4 \mathrm{~h}$ & $38.0 \mathrm{~g}$ & $1.32 \mathrm{~g}$ & $1.36 \mathrm{~g}$ & $1.38 \mathrm{i}$ & $0.43 \mathrm{f}$ & $0.45 \mathrm{f}$ & $0.48 \mathrm{f}$ & $0.89 \mathrm{ij}$ & $0.92 \mathrm{i}$ & $0.95 \mathrm{~h}$ \\
\hline \multirow[t]{2}{*}{ MSW } & $35.5 \mathrm{e}$ & $2.60 \mathrm{~g}$ & $29.3 \mathrm{f}$ & $43.1 \mathrm{~g}$ & $36.1 \mathrm{~h}$ & $1.28 \mathrm{~h}$ & $1.33 \mathrm{~h}$ & $1.34 \mathrm{k}$ & $0.40 \mathrm{~g}$ & $0.43 \mathrm{~g}$ & $0.47 \mathrm{f}$ & $0.91 \mathrm{i}$ & $0.93 \mathrm{i}$ & $0.97 \mathrm{~h}$ \\
\hline & \multicolumn{14}{|c|}{ El-Hosinia Plain Soil } \\
\hline TW & $40.0 \mathrm{~d}$ & $3.38 \mathrm{e}$ & $32.3 \mathrm{~d}$ & $51.4 \mathrm{e}$ & $44.1 \mathrm{e}$ & $1.39 \mathrm{f}$ & $1.42 \mathrm{f}$ & $1.45 \mathrm{~g}$ & $0.47 \mathrm{e}$ & $0.51 \mathrm{e}$ & $0.53 \mathrm{e}$ & $1.23 \mathrm{e}$ & $1.27 \mathrm{e}$ & $1.31 \mathrm{~d}$ \\
\hline MTW & $41.6 \mathrm{c}$ & $3.56 \mathrm{~d}$ & $33.3 \mathrm{~d}$ & $54.6 \mathrm{~d}$ & $43.7 \mathrm{e}$ & $1.43 \mathrm{e}$ & $1.47 \mathrm{e}$ & $1.51 \mathrm{e}$ & $0.52 \mathrm{~d}$ & $0.55 \mathrm{~d}$ & $0.57 \mathrm{~d}$ & $1.26 \mathrm{~d}$ & $1.34 \mathrm{~cd}$ & $1.36 \mathrm{c}$ \\
\hline SW & $26.0 \mathrm{i}$ & $2.06 \mathrm{k}$ & $21.7 \mathrm{i}$ & $36.1 \mathrm{ij}$ & $49.4 \mathrm{~b}$ & $1.52 \mathrm{~b}$ & $1.56 \mathrm{~b}$ & $1.59 \mathrm{~cd}$ & $0.56 \mathrm{~b}$ & $0.59 \mathrm{~b}$ & $0.64 \mathrm{~b}$ & $1.14 \mathrm{f}$ & $1.19 \mathrm{f}$ & $1.23 \mathrm{e}$ \\
\hline \multirow[t]{2}{*}{ MSW } & $28.0 \mathrm{~h}$ & $2.33 \mathrm{i}$ & $26.7 \mathrm{~g}$ & $38.5 \mathrm{~h}$ & $47.5 \mathrm{c}$ & $1.49 \mathrm{c}$ & $1.54 \mathrm{c}$ & $1.58 \mathrm{~d}$ & $0.54 \mathrm{c}$ & $0.59 \mathrm{~b}$ & $0.61 \mathrm{c}$ & $1.21 \mathrm{e}$ & $1.26 \mathrm{e}$ & $1.28 \mathrm{~d}$ \\
\hline & \multicolumn{14}{|c|}{ Soil of Exp. Farm at Fac. Agric. } \\
\hline TW & $45.0 \mathrm{~b}$ & $4.51 \mathrm{~b}$ & $46.0 \mathrm{~b}$ & $59.2 \mathrm{~b}$ & $35.8 \mathrm{~h}$ & $1.42 \mathrm{e}$ & $1.46 \mathrm{e}$ & $1.48 \mathrm{f}$ & $0.51 \mathrm{~d}$ & $0.55 \mathrm{~d}$ & $0.57 \mathrm{~d}$ & $1.35 \mathrm{~b}$ & $1.39 \mathrm{~b}$ & $1.40 \mathrm{ab}$ \\
\hline MTW & $47.0 \mathrm{a}$ & $6.15 \mathrm{a}$ & $51.3 \mathrm{a}$ & $61.0 \mathrm{a}$ & $33.5 \mathrm{i}$ & $1.45 \mathrm{~d}$ & $1.49 \mathrm{~d}$ & $1.53 \mathrm{e}$ & $0.54 \mathrm{c}$ & $0.57 \mathrm{c}$ & $0.58 \mathrm{~d}$ & $1.38 \mathrm{a}$ & $1.42 \mathrm{a}$ & $1.43 \mathrm{a}$ \\
\hline SW & $36.0 \mathrm{e}$ & $2.62 \mathrm{~g}$ & $31.0 \mathrm{e}$ & $43.5 \mathrm{~g}$ & $41.6 \mathrm{f}$ & $1.52 \mathrm{~b}$ & $1.56 \mathrm{~b}$ & $1.62 \mathrm{a}$ & $0.59 \mathrm{a}$ & $0.64 \mathrm{a}$ & $0.66 \mathrm{a}$ & $1.29 \mathrm{c}$ & $1.33 \mathrm{~d}$ & $1.37 \mathrm{bc}$ \\
\hline MSW & $39.0 \mathrm{~d}$ & $3.06 \mathrm{f}$ & $32.7 \mathrm{~d}$ & $45.6 \mathrm{f}$ & $38.3 \mathrm{~g}$ & $1.55 \mathrm{a}$ & $1.58 \mathrm{a}$ & $1.61 \mathrm{bc}$ & $0.56 \mathrm{~b}$ & $0.59 \mathrm{~b}$ & $0.62 \mathrm{c}$ & $1.34 \mathrm{~b}$ & $1.36 \mathrm{c}$ & $1.38 \mathrm{bc}$ \\
\hline
\end{tabular}

* TW, MTW, SW, MSW mean Tap Water, Magnetized Tap Water, Saline Water, Magnetized Saline Water, respectively.

\section{References}

Abou El-Yazied, A., El-Gizawy, A.M., Khalf, S.M. and Shalaby, O.A. (2012) Effect of magnetic field treatments for seeds and irrigation water as well as $\mathrm{N}, \mathrm{P}$ and $\mathrm{K}$ levels on productivity of tomato plants. J. Appl. Sci. Res. 8, 2088-2099.

Abul-Soud, M.A. and Abd-Elrahman, Shaimaa H. (2016) Foliar selenium application to improve the tolerance of eggplant grown under salt stress conditions. Int. J. Plant Soil Sci. 9, 1-10.

Ali, Y., Samaneh, R. and Kavakebian, F. (2014) Applications of magnetic water technology in farming and agriculture development: A review of recent advances. Current World Environment, 9, 695-703.
Alikamanoglu, S. and Sen, A. (2011) Stimulation of growth and some biochemical parameters by magnetic field in wheat (Triticum aestivum L.) tissue cultures. African J. Biotech. 10, 1095710963.

Amer, M.M., El-Sanat, A.G. and Rashed, S.H. (2014) Effects of magnetized low quality irrigation water on some soil properties and soybean yield (Glycine $\max$ L.) under salt affected soils conditions. J. Soil Sci. Agric. Eng., Mansoura Univ. 5, 1377-1388.

Chapman, H.D. and Pratt, P.F. (1961) Methods of Analysis for Soils, Plants and Waters. USA: California, Division of Agric. Sci., Berkeley Univ., 150-152. 
Grewal, H.S. and Maheshwari, B.L. (2011) Magnetic treatment of irrigation water and snow pea and chickpea seeds enhances early growth and nutrient contents of seedlings. Bio electromagnetic, 32, 5865 .

Hashemabadi, D., Zaredost, F. and Solimandarabi, M.J. (2015) The effect of magnetic water and irrigation intervals on the amount of the nutrient elements in soil and aerial parts of periwinkle (Catharanthus roseus L.). J. Ornamental Plants, 5, 139-149.

Hilal, M.H., El-Fakhrani, Y.M., Mabrouk, S.S., Mohamed, A.I. and Ebead, B.M. (2013) Effect of magnetic treated irrigation water on salt removal from a sandy soil and on the availability of certain nutrients. Int. J. Eng. Appl. Sci. 2, 36-44.

Klute, A. (1986) Methods of Soil Analysis, part I, $2^{\text {nd }}$ ed, USA: Madison, Wisconsin.

Mafakheri, A., Siosemardeh, A., Bahramnejad, B., Struik, P.C. and Sohrabi, Y. (2010) Effect of drought stress on yield, proline and chlorophyll contents in three chickpea cultivars. Aust. J. Crop Sci. 4, 580-585.

Maheshwari, B.L. and Grewal, H.S. (2009) Magnetic treatment of irrigation water: Its effect on vegetable crop yield and water productivity. Agric. Water Manage. 96, 1229-1236.

Mansour, M.M.F., Salama, Karima H.A. and Allam H.Y.H. (2015) Role of the plasma membrane in saline conditions: Lipids and proteins. Botanical Review, 81, 416-451.

Mansour, M.M.F. (2013) Plasma membrane permeability as an indicator of salt tolerance in plants. Biologia Plantarum, 57, 1-10.

Munns, R. and Tester, M. (2008) Mechanism of salinity tolerance. Annual Review Plant Biology, 59, 651-681.
Page, A.L., Miller, R.H. and Keeney, D.R. (1982) Methods of Soil Analysis, part II, $2^{\text {nd }}$ ed, USA: Wisconsin.

Peters, W., Beck, E., Piepenbrock, M., Lenz, B. and Schmitt, J.M. (1997) Cytokinine as a negative effector of phosphoenolpyruvate carboxylase induction in Mesembryanthemum crystallinum. J. Plant Physiol. 151, 362-367.

Ratushnyak, A.A., Andreeva, M.G., Morozova, O.V., Morozov, G.A. and Trushin, M.V. (2008) Effect of extremely high frequency electromagnetic fields on the microbiological community in rhizosphere of plants. Int. Agro-physics, 22, 71-74.

SAS Institute (1996) The SAS system for windows; Release 6.12; Statistical Analysis System Institute Inc, Cary (NC).

Shalaby, O.A. (2012) Magnetic bio-stimulation and its relevance to fertilizer requirements of tomato plants. Ph. D. Thesis. Horticulture Dept., Fac. Agric., Ain Shams Univ.

Sharma, P., Jha, A.B., Dubey, R.S. and Pessarakli, M. (2012) Reactive oxygen species, oxidative damage, and antioxidative defense mechanism in plants under stressful conditions. J. Botany, 1-26.

Troll, W. and Lindsley, J. (1955) A photometric method for the determination of proline. J. Biol. Chem. 215, 655-660.

Wang, Y., Zhang, B., Gong, Z., Gao, K., Ou, Y. and Zhang, J. (2013) The effect of a static magnetic field on the hydrogen bonding in water using frictional experiments. J. Molecular Structure, 1052, 102-104.

(Received: 6/9/2017; accepted: 9 / 11 /2017) 


\section{إستجابة نباتات القمح للري بالماء الممفن تحت ظروف الأراضي المصرية

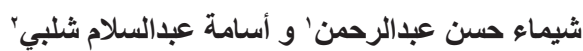

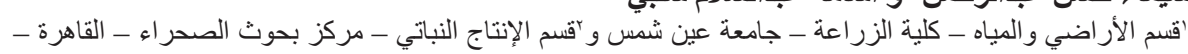

تم تصميم وتصنيع جهاز مغناطيسي لتقييم الآثار المترتبة على استخدام الماء الممغنط المالح في ري

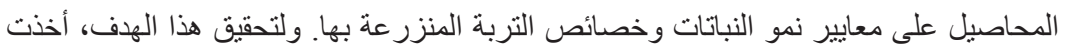

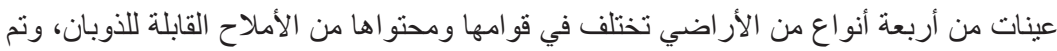

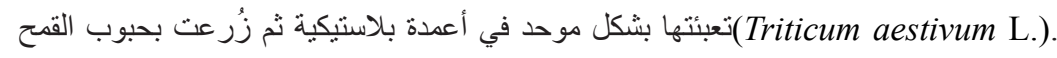

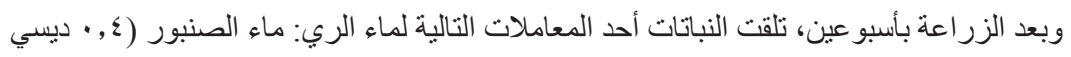

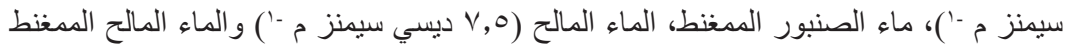

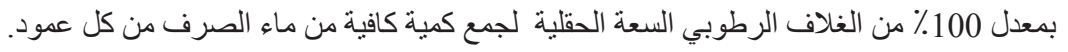

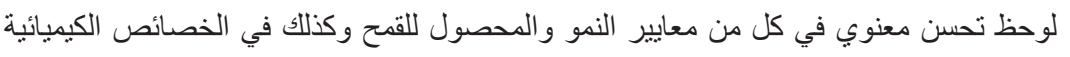

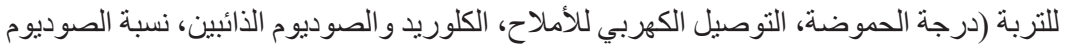

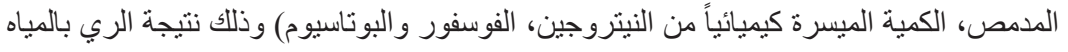

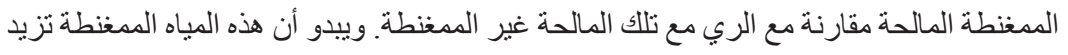

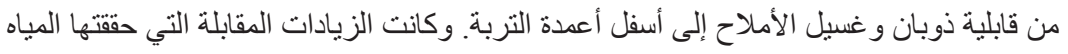

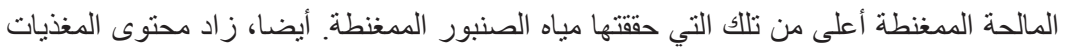

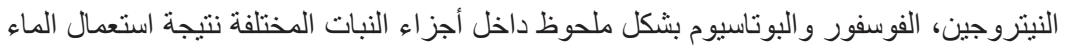

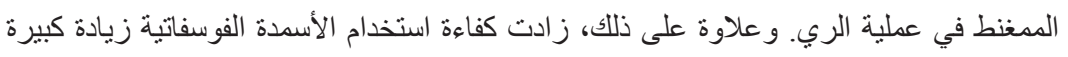

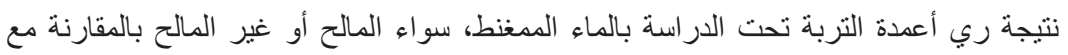

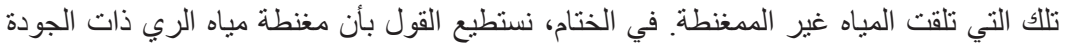

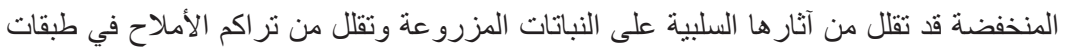

